UDC $811.111^{\prime} 42$

DOI https://doi.org/10.32838/2710-4656/2021.3-1/24

Zaitseva M. O.

Yaroslav Mudryi National Law University

\title{
COMMUNICATIVE SPECIFICITY OF ANGLOPHONE COURTROOM POLEMICS (LINGUISTIC ASPECT)
}

This article aims to establish the communicative specificity of Anglophone courtroom polemics. In order to achieve this goal, the following objectives are to be solved: to clarify the terminological apparatus involved in the article; to describe the communicative specificity of polemics in Anglophone court discourse; to establish the language means expressing polemics in Anglophone court discourse.

The aim, objectives and specificity of the material determined the choice of methods of analysis. At the stage of terminological grounding the main method is comparison, that is comparing the views of different scholars, directions of problem analysis, etc. Whereas at the second and third stages the following methods as classification (identifying linguistic means), generalisation (summarising information), argumentation (in support of its position) were used.

In our choice of approaches to the analysis we were guided by the contemporary scientific paradigms: cognitive linguistics, pragmatic linguistics, speech communication theory, lexicosemantic analysis methods. Elements of cognitive analysis helped to identify the dependence of court discourse on social conditions.

To carry out our research, we selected and described the authentic language material.

Based on the analysis of the linguistic material, it was established that each type of discursive personality in Anglophone court discourse is "assigned" a particular communicative mode. The judge as the dominant discursive personality in Anglophone court discourse uses a mentative communicative mode. The discursive personalities of an advocate and a prosecutor, unequal in status to the judge, argue within a narrative mode represented by diegesis and mimesis. In a debate, the judge realises his or her dominant position by using certain linguistic resources. The speech behaviour of the lawyer and the prosecutor during the debate demonstrates their unequal status in relation to the judge, which can be seen in the use of language that emphasises their dependent position.

Key words: Anglophone court discourse, discursive personalities, communicative mode, mentative, narrative, linguistic means.

Introduction. This study sheds light on the communicative specificity of Anglophone courtroom polemics. The analysis, in our view, must begin with an interpretation of the relationship in the dichotomous pair "law and language". Law is inseparable from language, from expression in language. The involvement of participants in the process of law making is one of the specific characteristics of court discourse. It is possible to argue that participants engaged in any kind of discourse are also involved in the creation of one kind of discourse or another, to name but few, political discourse, mass-media discourse, theatrical discourse, pedagogical discourse, etc. However, there is a lived but ignored fact that the specificity of participants' involvement in the creation of judicial discourse is often complicated. I should like to stress, it is complicated by the fact that "law exists in a continuous sense-making about the text of law, a multiplication of replenishing intermediaries who produce meaning and draw it out; rewriting what is relegated, disguised, namely the struggle for power and truth in society" $[1$, p. 22]. The hope for truth, the expectation of a "just retribution" from the law, is an essential modus operandi of human existence in principle. As a semiotic model, justice manifests its significance when the expected justice "...is played out as a drama in which retribution for the violation of the prohibition is recounted, hence any criminal case is a story of the struggle of evil against good and the affirmation of an ethical choice in favour of good" [1, p. 25]. In line with this, it is therefore important for the sender of the speech in court to relate his role and his speech activities to a position of goodness, a position of affirmation of the truth in the eyes of the jury, the public and the witnesses. Thus, on the one hand, polemics in court should be constructive, aimed at finding the truth. On the other hand, it is not an argument for the sake of an argument, not just immersion in a conflict context, but the need to confront in a way that is sure to win in 
court, i.e. aimed at success. All this makes for a communicative specificity of court discourse.

The study is conducted in the communicative and discursive paradigm. The object of the study is modern Anglophone court discourse, which is a communication of both equal-status communicators (judge - judge) and unequal-status communicators (judge - prosecutor, judge - advocate). The subject of the study is Anglophone courtroom polemics from the point of view of its linguistic representation.

The relevance of the research is due to the lack of study of communicative specificity of court discourse in general and courtroom polemics in particular.

Recent researches analysis. As a communicative specificity of court discourse, we note that the participants in a trial act within the established ceremoniality of action, which is based not only on two basic principles: reverence and the ability to behave [3, p. 98], but also on the principle of communicative expediency. Participants in court proceedings during court debates "act out" the so-called courses of action, in other words, "patterns of verbal and non-verbal acts" [3, p. 18]. Through such patterns, the communicant expresses his or her view of the situation and evaluates the other participants. The pattern here acts as a discursive practice, that is, a "way of speaking in a particular social domain or social institution that reflects the lived experience and knowledge of the participants in the communication" [6].

It is worthwhile to bear in mind that the way of speaking in court discourse is determined by a strictly established ritual and the role of each participant in the process, the observance of which is not subject to change. The aim of the established ritual behaviour is different for each type of discursive language personality in judicial discourse, but in any case, it involves "scoring as many points as possible for oneself in relation to the opponents and getting as many benefits as possible. The presence of an audience is almost mandatory for such a contest" [3, p. 40]. Common to all litigants is the attitude to present facts favourable to themselves and facts unfavourable to others in such a way as to demonstrate a better mastery of the situation in comparison with the opponent. As many scholars have amply pointed out, today the ability to demonstrate mastery of the situation and build one's image is often even more important than a credible presentation of information. This is especially true in the modern era of image influence in a continuous flow of information, where image is used to convey as much information as possible in a minimum of time. A result of the increasing flow of image-containing information messages is that "people-images, both living and fictional, play an essential role, creating patterns of behaviour, roles and situations, according to which we draw conclusions about our own lives" [8]. However, it should not be forgotten that in the context of litigation, all of the above is complicated by the constant presence of conflict and constant polemics between the parties. Thus, the aim of the paper is to establish the communicative specificity of polemics in modern Anglophone court discourse.

In order to achieve this goal, the following objectives are to be solved:

1) to clarify the terminological apparatus involved in the article;

2) to describe the communicative specificity of polemics in Anglophone court discourse;

3) to establish the language means expressing polemics in Anglophone court discourse.

Research methods and techniques. The aim, objectives and specificity of the material determined the choice of methods of analysis. At the stage of terminological grounding the main method is comparison, that is comparing the views of different scholars, directions of problem analysis, etc. Whereas at the second and third stages the following methods as classification (identifying linguistic means), generalisation (summarising information), argumentation (in support of its position) were used.

In our choice of approaches to the analysis we were guided by the contemporary scientific paradigms: cognitive linguistics, pragmatic linguistics, speech communication theory, lexico-semantic analysis methods. Elements of cognitive analysis helped to identify the dependence of court discourse on social conditions.

To carry out our research, we selected and described the authentic language material.

Results and discussion. To put the key point explicitly, the ritual of the court session, as we have noted, involves a) the ability to behave, rather, to present oneself - the ritual of presenting oneself/ image-making - and b) deference to the dominant person - the judge, consisting in expressions of respect and avoidance.

In sociology, some scholars have considered the issue of distance in relation to social classes, "the higher the class, the more extensive and complex the taboos regarding contact" [3, p. 82]. In judicial discourse, the same is observed in relation to the dominant personality of the judge, when partisans, while expressing deference to the judge, seek not to violate the distance, thus recognising his inviolability. 
This, in fact, is the "ritual of avoidance", whereas other participants in the process do not possess such properties. Maintaining the ceremonial distance in court discourse does not even imply a demonstration of respect, which, incidentally, may not exist, for the judge, but recognition and marking the judge's status as a dominant personality.

It may be added at this point that a similar ritual of deference and avoidance is also observed in the relations between advocates and prosecutors in court discourse. Although the degree of expression of these rituals is reduced as the ceremonial distance between these participants in the proceedings is reduced, i.e. the "personal protected area" may be broken and "familiarity" between these participants may be shown.

There is already an unequal ceremonial relationship between the judge on the one hand and the prosecutor and the lawyer on the other. It manifests itself in the fact that they can be asked any question, which can be rejected or approved by the judge as the guarantor of ceremonial relations in the court, who establishes order in the trial process. Thus, in a legal newspaper we read, "Persons present in the courtroom must stand when the court enters and exits. The decisions of the court shall be heard standing up by all those present in the courtroom. Participants in the process and other persons present in the courtroom shall address the court and one another standing up, give explanations, testimonies, conclusions, and consultations. It is customary to speak in the process only with the permission of the presiding officer. In court, it is strictly forbidden to argue with the judge; to interrupt the judge; to ask the judge or the prosecutor questions; to explain anything to the judge; to show emotion; to descend into personal humiliating attacks on the participants of the process" [7]. Let us note this as confirmation of our conclusions that the judge is a dominant discursive linguistic personality, since the code of conduct of the participants first specifies the rules towards the judge and only then the rules of conduct towards the other participants in the process.

The empirical materials of the study have made it possible to establish that of the two aspects of adhering to the principle of ceremonialism in relation to the dominant discursive linguistic personality in court, that is, in the expression of deference and avoidance as a mode of maintaining ceremonial distance, it is the ritual of maintaining ceremonial distance that nowadays becomes of paramount importance. Whereas the ritual of respecting deference is becoming secondary. In our view, this suggests that discursive practices that depend on the attitude, the modality, are a dynamic structure. The change of attitude, modality transforms discursive practices, the understanding of which is based on conceiving practices "as activities and social experiences given in direct observation" [6]. However, not all discourses undergo a complete change of attitude or modality, but only those that are not confined and complete. My point here is that judicial discourse is in many ways a closed and complete system, so it does evolve, but not as quickly and dramatically as, for example, mass media discourse, political discourse. It may be added at this point that in judicial discourse, the violation of the ceremonialism of action is not even seen as a violation of traditional relations, but as a threat to the balance of the system as a whole.

An important focus of the ceremonialism of judicial actions is not only the non-verbal actions that are obligatory for the actor, but also the verbal behaviour that provides for how to enter into an argument with an opponent, a judge, how to ask questions, etc. Thus, W. O'Barr, analysing the speech behaviour of actors in court, writes that the way the way a person speaks may be more important than what is said, "It is common knowledge that how something is said may be more important than what is actually said" $[10$, c. 1]. We find ourselves in full agreement with A. S. Aleksandrov who remarks that in court: "about the 'promised' justice, a drama is played out that tells of retribution for the violation of the prohibition" [1, p. 24].

Thus, participants` verbal behaviour becomes one of the most important characteristics of polemics in judicial discourse. Let us dwell in this connection on the notion of style of speech behaviour. The term "speech style" is introduced by W. O'Barr in "Linguistic Evidence: Language, Power, and Strategy in the Courtroom" (1982), who distinguishes such styles of speech behaviour or speech styles in the courtroom as speech behaviour demonstrating power (powerful speech), speech behaviour demonstrating no power (powerless speech). Speech behaviours that demonstrate power and speech behaviours that demonstrate a lack of power affect the perception of the speaker. In particular, listeners may view the use of "strong style" with the use of certain language means as a reflection of high status and tend to view such participants favourably. Powerful speech is characterised by the use of legal language as a tool to control, regulate, impose obligations and pass judgement: "...law uses its language as an instrument, through which people are ruled, regulated, obligated, and judged" $[10$, p. 25]. This kind of speech behaviour is realised in the mentative mode. 
Mentative mode implies above all an attitude of domination over the addressee. Speech activity in the mental mode aims at affecting firstly and persuading secondly. Mentative is a class of discursive practices, which "do not simply inform about states or processes of being or thinking, but assume - as a consequence of communicative event - some mental event (change of world picture) in the addressee's mind" [9, p. 40]. Mentative, per se, expresses power in discourse, suggesting a certain mental impact. Let us explain the above with the help of examples. The examples given below are taken from case 14-185 of 2014, which was heard by the US Supreme Court. Thus, only the judge has the right to ask questions in court to any participant:

JUSTICE KENNEDY: Can you explain why...? But why that is not a crime involving moral turpitude? ... why did the Fifth Circuit treat this, therefore, as a-as it requested review the sua sponte extension granted below? Why? Why would one that?

JUSTICE GINSBURG: Would the Fifth Circuit, with this rulemaking, you can't tell us what it is at this stage, this early stage, would it be available, will they have a rule should we remand this case to the Fifth Circuit?

CHIEF JUSTICE ROBERTS: Where... where is Mr. Mata at this point?

A further feature of polemics in judicial discourse is the use of humour. The judge, as the dominant discursive person, is able to make jokes in the courtroom, while other participants are limited in this regard. Moreover, jokes on their part are not considered appropriate. Here are some examples from the case cited:

JUSTICE KENNEDY: You know the way to our hearts. (Laughter.)

JUSTICE KAGAN: He's definitely Justice Scalia. (Laughter.)

JUSTICE KAGAN: And we're not often confused. (Laughter.)

JUSTICE SCALIA: It's a good question, though. (Laughter.)

Judges may use expressive language:

JUSTICE GINSBURG: Can you explain why on the surface, he beats up his girlfriend.

The judge may re-question (1), clarify (2) and even interrupt (3):

(1)JUSTICE SOTOMAYOR: Now, I've - I've forgotten, but is there a circuit split on that third on the sua sponte review?;

JUSTICE KAGAN: I'm sorry, but there would be an NPR when? Late this calendar year?

(2) JUSTICE GINSBURG: What if ...;
JUSTICE KAGAN: And Mr. Yang, could you point me to the place in the board's decision that you think makes clear what the board was doing?;

JUSTICE KAGAN: So on that assumption, that would, as I understand it, give the Fifth Circuit something new to think about in - in addressing this question; is that right?

(3) MR. FLEMING: It's ...

JUSTICE SCALIA: Why... why would it have done that if it - if it thought that, in fact, there was some argument;

MR. FLEMING: The ...

JUSTICE SCALIA: I thought all it did was...;

MR. FLEMING: Now, because they have not ...

JUSTICE SCALIA: Which means there... there's no equitable tolling.

For speech behaviour that demonstrates a lack of power corresponds, in our view, to the mode of narrative. Toward this end, this paper briefly explains the notion of narrative. Narrative acts as a model, a specific form of discourse, and is defined as "an ensemble of linguistic and psychological structures transmitted culturally and historically, limited by the level of skill of each individual and a mixture of his or her social and communicative abilities with linguistic skill" [2, p. 30].

The discursive person in judicial discourse with a speech behaviour that demonstrates a lack of authority also uses certain linguistic means in judicial polemics: addressing the judge with title and surname, using the modal verb may, the noun permission, a constant manifestation of gratitude:

MR. YANG: Mr. Chief Justice, and may it please the Court...

MR. FLEMING: Mr. Chief Justice, and may it please the Court...

MR. FLEMING: I try to please, Justice Kennedy.

MR. FLEMING: With the Court's permission, I'll reserve the balance of my time. Thank you.

MR. FLEMING: It did, Your Honor

The speech behaviour of an unequal status discursive personality within a narrative communicative mode may be subject to correction by a judge, e.g:

MR. YANG: That's right. We disagree with Alderson Reporting Company Official Petitioner on this point...

JUSTICE SCALIA: On that point.

JUSTICE KAGAN: But, I mean, you can't really operate very well if you can't figure it out.

MR. YANG: Well, that's true.

Within the boundaries of the narrative communicative mode, we will distinguish its forms, such as diegesis and mimesis. 
The first mode of storytelling describes objects and events literally, the so-called "simple narrative" [4, p. 60]. The sender of the speech impartially describes the course of events. The prosecutor's speech is usually an example of diegesis:

MR. YANG: The court of appeals here rested its decision on a basic and fundamental error of administrative law. Rather than review the board's decision on its own terms, the court of appeals recharacterized the question before it into a different question over which it lacked jurisdiction. That course is inconsistent with the Chenery rule, which, since even before the APA, required that judicial review of agency action be based on the rationale adopted by the agency.

MR. YANG: But the construal rule itself is just fundamentally into the teeth of the Chenery doctrine. And had the court of appeals recognized that what it had to review was the denial of the alien's motion to reopen, it would have had jurisdiction.

Note here the abundance of professional vocabulary and the official style expressed both lexically and grammatically, e.g. the sentence with the Subjunctive I: That course ... required that judicial review of agency action be based...

Sentence with inversion: And had the court of appeals recognized...

The second mode of storytelling contrasts with the first and describes objects and situations as dramatic events. Mimetic storytelling aims to "play out a kind of spectacle that passes off the copy as the original and leads away from the truth" [5]. An advocate usually uses it:

MR. FLEMING: The Court has been offered two ways to approach this case, a short way and a long way. We believe we prevail under both and I will address both, but I would start with the short way, which we think is the right way. This is a case about appellate jurisdiction...

We should pay attention to the metaphor based on the antonyms short - long. The advocate tries to influence the recipients with such lexical means as prevail, right way which can be grouped into the thematic group "unconditional triumph".

MR.FLEMING: ...But I-I want to be clear, we we do not fear this question at all. And if the

Court wishes to reach the merits issues that Mr. Peterson has put before the Court, we are happy to fight on that ground. We simply want it to be plain...

It should be noted here that the advocate stresses that they will get a positive decision from the court because they have the advantage in the dispute on their side. He is not afraid to enter into an argument because of the irrefutability of his evidence. The language means do not fear... at all, happy to fight, simply want are united by the seme "willingness to act because of their assertion of rightness".

Conclusions. The ritualism of the court session does not involve a change of communicative modes. Each type of discursive personality in judicial discourse is "assigned" a certain communicative mode. Analysing the correlation between narrative and mentative modes, we conclude that the mentative communicative mode is used by the judge as the dominant discursive personality in judicial discourse.

The discursive identities of the advocate and the prosecutor that are unequal in their status in relation to the judge, argue within a narrative mode represented by diegesis and mimesis. The diegetic storytelling implies an impartial presentation of events by the prosecutor, so the use of official and professional vocabulary and grammatical means inherent to the official style becomes characteristic to the form. Whereas a mimetic description seeks to dramatise events and make an obvious show of being right, so the lawyer uses figurative lexical means and grammatical means that are characteristic of the conversational style.

During the debate, the judge realises his dominant position by using the questioning form, allowing for clarification and interrogation. He may interrupt the lawyer and the prosecutor while they are speaking. The judge may make jokes during the debate and use expressive language. Moreover, it is not stipulated by the ceremonial rules for the judge to use certain linguistic means.

The speech behaviour of the lawyer and the prosecutor during the controversy demonstrates their unequal status in relation to the judge, which is manifested by the fact that they do not use the question form, resort to constant polite address to the judge, and use linguistic means that emphasise their dependent position.

As a communicative specificity of judicial discourse, we would like to note that the participants in the judicial process act within the established ceremonialism of action, which implies the imposition of certain above-mentioned restrictions on the disputing parties.

This piece of research has theoretical and practical value. We can stress the importance of the value of our paper in its original analysis of the speech behaviour of such discursive personalities in the course of judicial polemics as judge, prosecutor and advocate.

The practical value of the paper is in providing the possibility of using its provisions and conclu- 
sions, the factual material in the study of communicative science, psycholinguistics, discourse analysis, in the practice of translation, linguistics and area studies, in the course of legal writing, oratory.

It is worthwhile to bear in mind that for reasons of scope of the article, we were not able to fully cover all the issues of interest related to the communicative specificity of courtroom polemics. Therefore, we would like to note that the study is promising in terms of dealing with such issues as the features of speech behaviour in polemics of other litigants, e.g. defendants, witnesses, experts.

\section{References:}

1. Александров А. С. Язык уголовного судопроизводства : автореф. дис. ... докт. юрид. наук : 12.00.09. Нижний Новгород, 2003. 60 с.

2. Брокмейер Й., Харре Р. Нарратив: проблемы и обещания одной альтернативной парадигмы. Вопросы философии. 2000. 3. С. 29-42.

3. Гофман И. Ритуал взаимодействия. Очерки поведения лицом к лицу. Москва : Смысл, 2009. 319 с.

4. Женетт Ж. Фигуры : в 2 т. Москва : Изд-во им. Сабашниковых, 1998. Т. 1. С. 60-281.

5. Компаньон А. Демон теории. Литература и здравый смысл. Москва : Изд-во Сабашниковых, $2001.336 \mathrm{c}$.

6. Понятие дискурсивной практики. Myfilology.ru - информационный филологический ресурс. 2016. URL: https://myfilology.ru//yazykoznanie/poniatie-diskursivnoi-praktiki/ (дата звернення 01.05.2021).

7. Студенников С. Как выступать в суде и как себя правильно вести: примеры из практики. Судовоюридична газета. 22.03.2019. URL: https://sud.ua/ru/news/publication/138023-kak-vystupat-v-sude-i-kaksebya-pravilno-vesti-primery-iz-praktiki (дата звернення 01.05.2021)

8. Тоффлер Э. Шок будущего. Москва : ООО «Издательство АСТ», 2002. 557 с.

9. Тюпа В. И. Коммуникативные стратегии теоретического дискурса. Критика и семиотика. 2006. Вып. 10. С. 36-45.

10. O'Barr W. Linguistic Evidence. Language, Power and Strategy in the Courtroom. New York, London, Paris, San Diego, San Francisco, Sao Paulo, Sydney, Tokyo, Toronto : Academic Press, 1982. 192 p.

\section{Зайцева М. О. КОМУНІКАТИВНА СПЕЦИФІКА АНГЛІЙСЬКОМОВНОЇ СУДОВОЇ ПОЛЕМІКИ (ЛІНГВІСТИЧНИЙ АСПЕКТ)}

Метою статті є встановлення комунікативної спеиифіки англійськомовної судової полеміки. Для досягнення зазначеної мети необхідно вирішити такі завдання: уточнити термінологічний апарат y статті; описати комунікативну спеиифіку полеміки в англійськомовному судовому дискурсі; встановити мовні засоби, що виражають полеміку в англійськомовному судовому дискурсі.

Мета, завдання і специфіка матеріалу зумовили вибір методів аналізу. На етапі термінологічного обтрунтування основним методом є порівняння, тобто зіставлення поглядів різних учених, напрямів аналізу проблеми $і$ т. д., тоді як на другому і третьому етапах використовувалися такі методи, як класифікація (виявлення мовних засобів), узагальнення (узагальнення інформації), аргументація (на підтримку своєї позииії).

У виборі підходів до аналізу ми керувалися сучасними науковими парадигмами: когнітивною лінгвістикою, прагматичною лінгвістикою, теорією мовної комунікачії, методами лексикосемантичного аналізу. Елементи когнітивного аналізу допомогли виявити залежність судового дискурсу від соиіальних умов.

Для проведення дослідження був відібраний і описаний автентичний мовний матеріал.

На основі аналізу мовного матеріалу було встановлено, щуо за кожним типом дискурсивної особистості в англійськомовному судовому дискурсі «закріплений» певний комунікативний режсим. Суддя як домінуюча дискурсивна особистість використовує ментативний комунікативний режим. Дискурсивні особистості адвоката і прокурора, які є нерівними за своїм статусом судді, сперечаються у рамках наративного режиму. Останній може бути у формі дієгезу і мімезису.

Під час дебатів суддя реалізує своє домінуюче положення, використовуючи певні мовні засоби. Мовна поведінка адвоката і прокурора у полеміиі демонструє їх нерівний статус щодо судді, що проявлясться у використанні мовних засобів, які підкреслюють їхнє залежне становище.

Ключові слова: англійськомовний судовий дискурс, дискурсивна особистість, комунікативний режим, ментатив, наратив, мовні засоби. 